\title{
Music Learning Based on Computer Software
}

\author{
https://doi.org/10.3991/ijet.v12.i12.7961 \\ Baihui Yan( $\left.{ }^{\varpi}\right)$, Qiao Zhou \\ Add Jiangxi Science \& Technology Normal University, Nanchang, Jiangxi, China \\ 416368467 @qq.com
}

\begin{abstract}
In order to better develop and improve students' music learning, the authors proposed the method of music learning based on computer software. It is still a new field to use computer music software to assist teaching. Hereby, we conducted an in-depth analysis on the computer-enabled music learning and the music learning status in secondary schools, obtaining the specific analytical data. Survey data shows that students have many cognitive problems in the current music classroom, and yet teachers have not found a reasonable countermeasure to them. Against this background, the introduction of computer music software to music learning is a new trial that can not only cultivate the students' initiatives of music learning, but also enhance their abilities to learn music. Therefore, it is concluded that the computer software based music learning is of great significance to improving the current music learning modes and means.
\end{abstract}

Key words-music learning classroom, computer software, assisted teaching

\section{Introduction}

Today's society has entered the information age. All countries and regions has taken information technology as a major strategic goal of education in order to meet the rapid development of information technology. As one of the means of modern information technology, computer music software poses challenges to the current music education. At the same time, it also provides us with technical, methodological and cognitive tools for quality education, playing the irreplaceable role in deepening music education reform and developing the students' music potential [1]. At present, there are widespread problems in primary school music teaching in China, such as ignoring students' interest in music learning, outdated content and small amount of information. Computer music software applications can help teachers solve such problems effectively [2]. With lively interfaces and flexible means, it adds spice to boring exercises. With rich teaching contents of rhythm, listening skills, music recognition, music theory and musical instrument, it becomes an effective teaching assistant, a good partner for students to learn independently, and an indispensable condition for modern music education [3].

The use of computer music software in primary school music teaching is meaningful in developing the interest of music learning, improving music learning ability, changing teaching and learning styles, supplementing evaluation methods, remedying 
insufficient school software, and establishing the relationship between computer learning, English learning and itself.

\section{$2 \quad$ Literature review}

\subsection{Foreign literature review}

In foreign terms, developed western countries have paid close attention to the application of computer music software in primary school music teaching. Many primary schools began to use computer music software for teaching in the late 1980s. According to the arts standard in America, there shall be computer music teaching in each stage from kindergarten to the twelfth grade [4]. In 1993, the "Goals 2000: Educate America Act" was promulgated, setting up the national standard for music education and announcing that non-traditional sound source including electronic and acoustic media (such as personal computer and MIDI, i.e. keyboard, sequencer, synthesizer, and drum machine) should be used in composition and arrangement for students in the $5^{\text {th }}-8^{\text {th }}$ grades. In addition to government regulations, there are American software companies specializing in music education software development. The application of computer music is also regulated in the music course standards in Japan, British, France, Germany and other developed countries. With the progress of information technology, the changes of the teaching and learning means of music courses in primary schools will inevitably promote the development of music education [5].

\subsection{Domestic literature review}

In domestic terms, the application of computer music software in primary school music teaching has just started up. Compared to that in the Mainland, computer music in Hong Kong and Taiwan developed more rapidly, with complete hardware and software configuration and substantial information of computer music in their websites [6]. The computer companies in Hong Kong and Taiwan are more advanced and standard in developing and manufacturing music teaching software and in training teachers to use them. Currently, the mainland computer software companies have discovered the huge potential to develop the market of children music software. A succession of computer music software (TT composer, Eyesong, etc.) emerges, which provides abundant learning resources for primary school students. The existing Chinese Curriculum Standard for Music regulates that music teaching should take full advantage of modern technical means and, for the first time, produces multi-media disc for new textbooks [7]. 


\section{The relationship between computer music software and music learning}

\subsection{Computer music software-assisted music teaching}

Music is sound in essence. Because music is the art of sound, the starting point and destination of music learning cannot leave the "audible" sound. The learning materials in music class are all "visible" words and graphics instead of the music itself. These visible staff are merely the assistance of "audible" sound. The reason for the need to shift between sound and vision (music score) is that the auditory discrimination and memory is much poorer than the visual ones as a result of the unbalanced development of physiological functions [8]. The vision-sound shift is just what the computer is good at. The basic principle of computer music lies precisely in its "event separation" feature. With the help of computer music software, auditory and visual senses are repeatedly contrasted to integrate the listening, singing and composing into a whole. By activating a variety of sense organs of students, the learning effect will be much better than the use of a single organ [9]. Therefore, the efficiency and quality of music learning will be improved significantly with the help of computer music software [10].

\subsection{The application of computer music software in music teaching}

In the course of the research, we find that the traditional music teaching and learning modes are not suitable for this subject. Through times of experiments, we draw on the experience of prevailing music teaching modes both at home and abroad, to build a basic model of computer music software-assisted music teaching. Taking the 1st and 2nd-3rd grades of middle schools as examples, the model is shown in Figure 1 and Figure 2. 


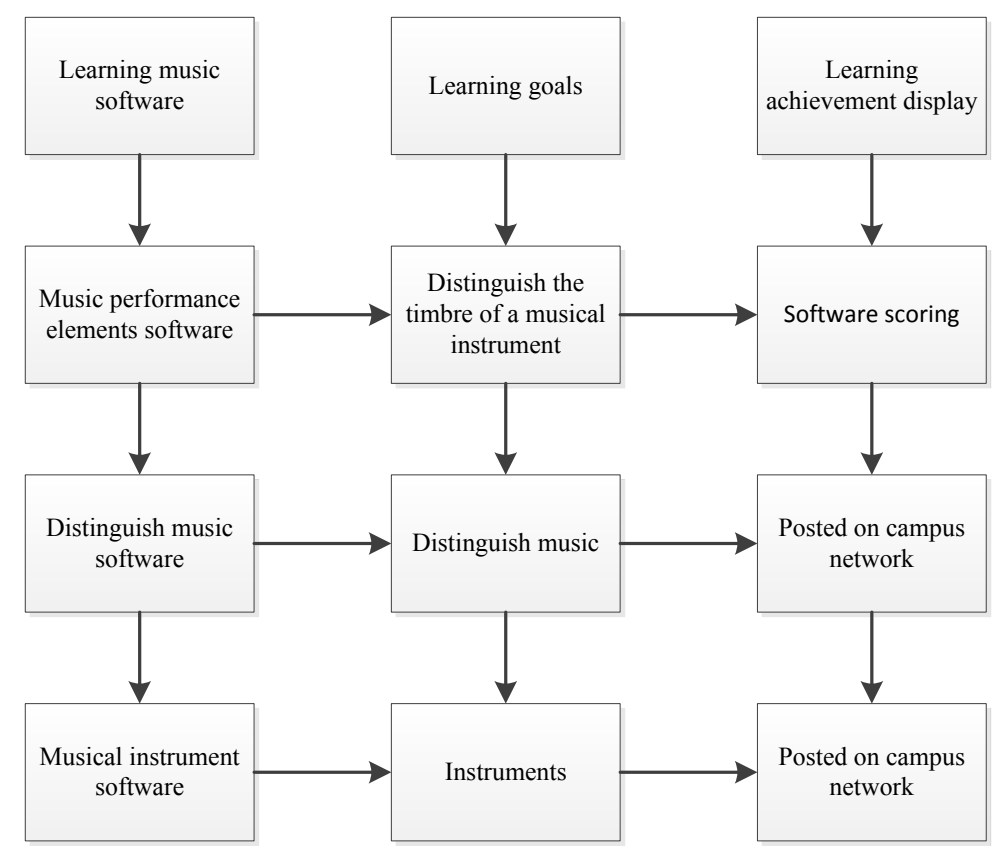

Fig. 1. The basic model of music teaching in grade one

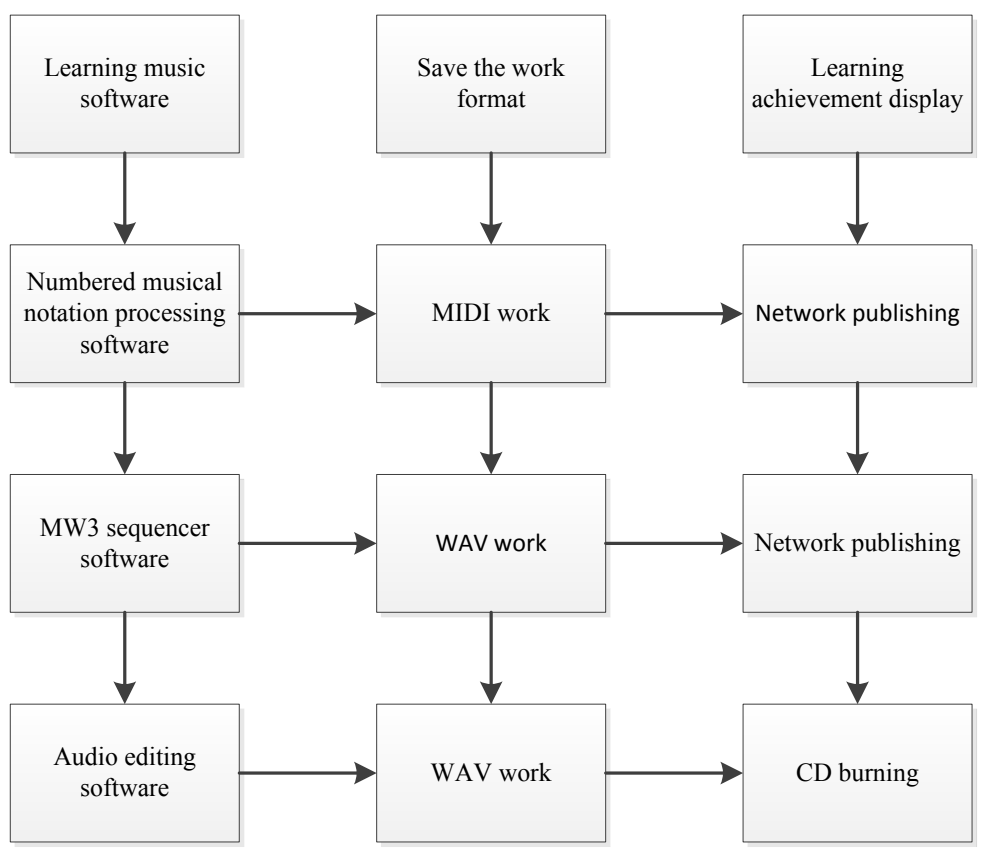

Fig. 2. The basic model of music teaching in grades 2-3 


\section{3 the correlation analysis of computer music software and teaching quality}

This study examines the interrelationship between computer music software and teaching quality from three aspects: teaching content, computer music software appearance and programming. The results are shown in Table 1.

Table 1. The relationship between computer music software and teaching quality

\begin{tabular}{|l|c|c|c|c|c|c|}
\hline \multirow{2}{*}{} & \multicolumn{2}{|c|}{ teaching content } & \multicolumn{2}{c|}{ computer music software appearance } & programming \\
\cline { 2 - 7 } & $\begin{array}{c}\text { Information } \\
\text { amount }\end{array}$ & $\begin{array}{c}\text { Content } \\
\text { selection }\end{array}$ & $\begin{array}{c}\text { Character } \\
\text { matching }\end{array}$ & $\begin{array}{c}\text { Color } \\
\text { matching }\end{array}$ & $\begin{array}{c}\text { mage mat- } \\
\text { ching }\end{array}$ & Program run \\
\hline Teaching quality & 0.579 & 0.679 & 0.642 & 0.678 & 0.591 & 0.397 \\
\hline Sig & 0.433 & 0.433 & 0.433 & 0.433 & 0.433 & 0.433 \\
\hline
\end{tabular}

(Note: $* \mathrm{p}<.05)$

As can be seen from the table: From the quality of computer music software, the teaching information amount, teaching content, and teaching effect have a linear correlation between each other; teaching quality is evidently correlated with character matching, color matching, and image matching. However, the program run is nonlinear to the teaching quality.

\section{$4 \quad$ Music learning development status analysis}

\subsection{Student Music Learning Survey}

We take a certain school as an example to conduct a survey on music learning. The survey result shows that the age of secondary vocational students are mainly distributed in 14-24, and that the music learning interests will change with age. Figure 3 shows the age distribution of students.

As can be seen from the figure, the majority of students are mainly aged 14 to 24 , which is related to the multi-level running mode supplemented by short-term training with academic education as the mainstay. At this stage, students mainly focus on the internship and the ability to work, and thus the music lessons may suspend or be replaced with music theory courses.

The survey also finds that the total number of boys who like music at the age of 17 is shrinking, indicating that the number of boys who like music at this age is less than that of girls. The female interests in music shows a steady development. Compared with other ages, they demonstrate a strong interest in music, which means they are highly malleable in this stage. 
Short Paper-Music Learning Based on Computer Software

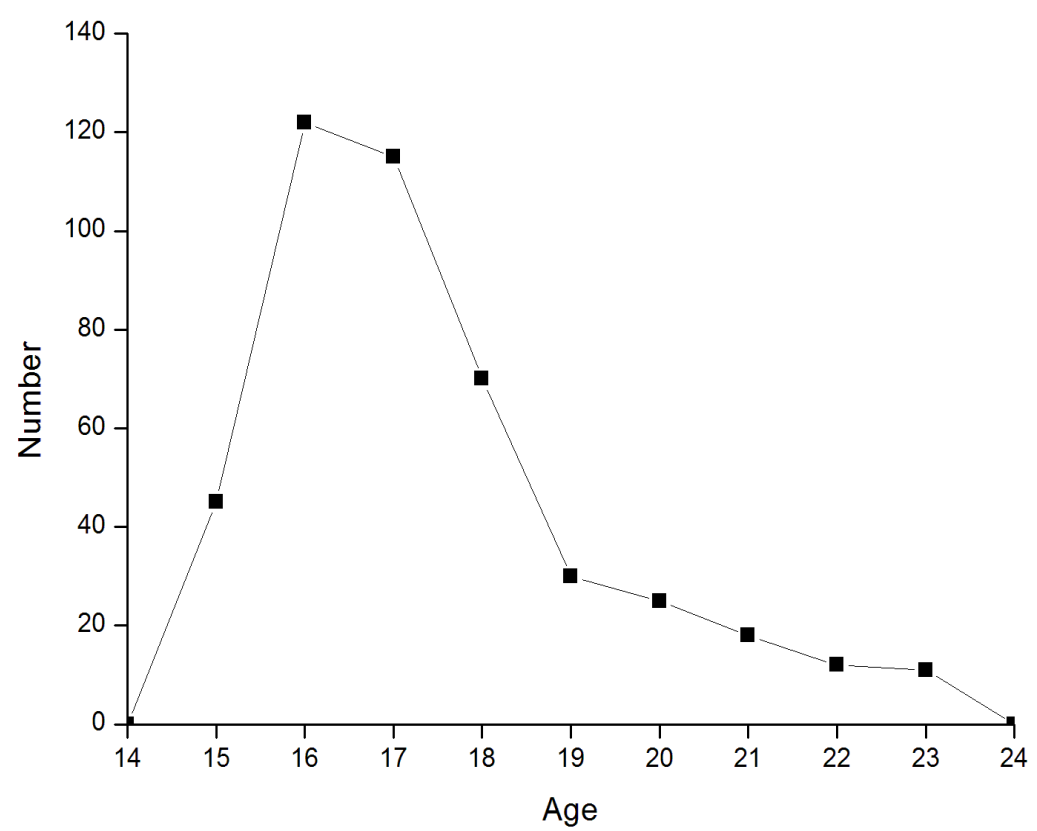

Fig. 3. Age distribution of students

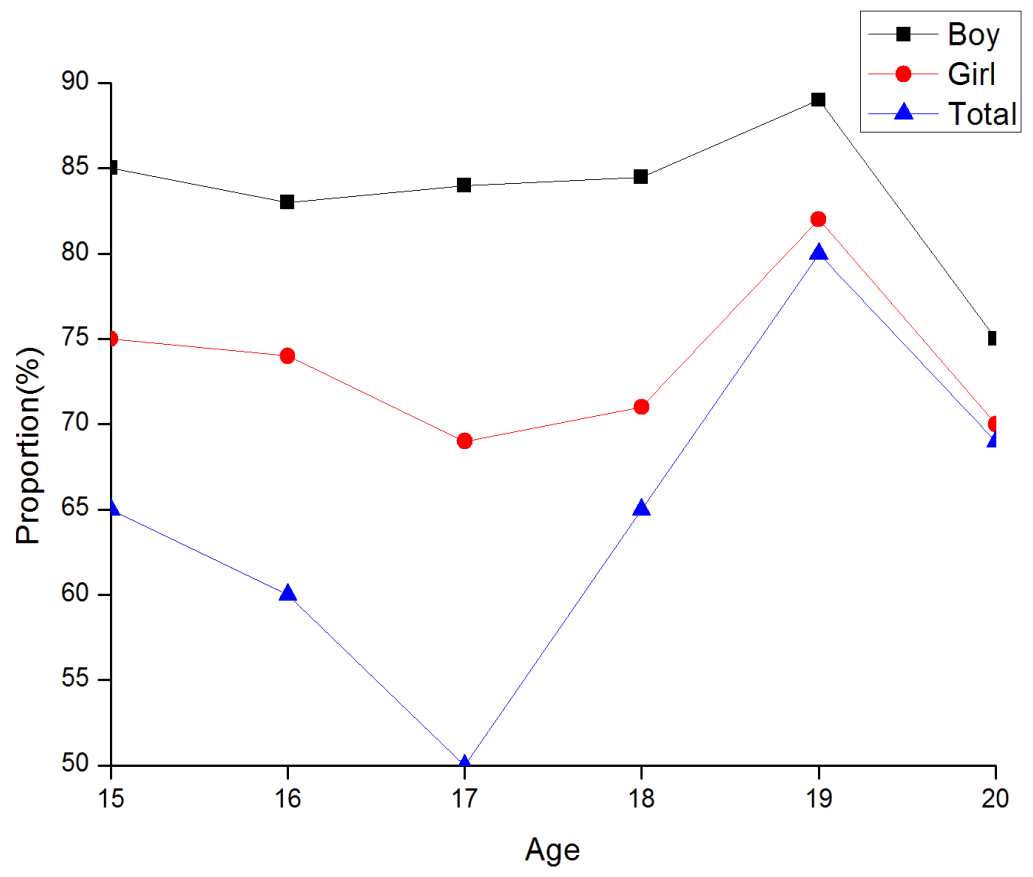

Fig. 4. Proportion of age and student's love for music 
As can be seen from Figure 4, the proportion of girls who enjoy music in all age groups has always been higher than that of boys, with the most obvious difference being 17 years old when girls are $32.35 \%$ more than boys to enjoy music. The gap is the least obvious at 19 years old when $9.72 \%$ more girls than boys like music. In contrast, the girls' state of music fondness is relatively steady, which is related to the characteristics of girls. The learning environment in campus is the reflection of the female students' dependence on music learning, and also determined by the social status of women and the division of roles.

\subsection{In-class music fondness degree analysis}

Through the music class survey, we find that students have different understandings of music learning in class. Some support music learning while others dislike them. In order to prove the effectiveness of computer music software in music learning, we investigate the music classrooms in cities, towns and villages. The analytical figures results are shown in Figure 5 and Figure 6:

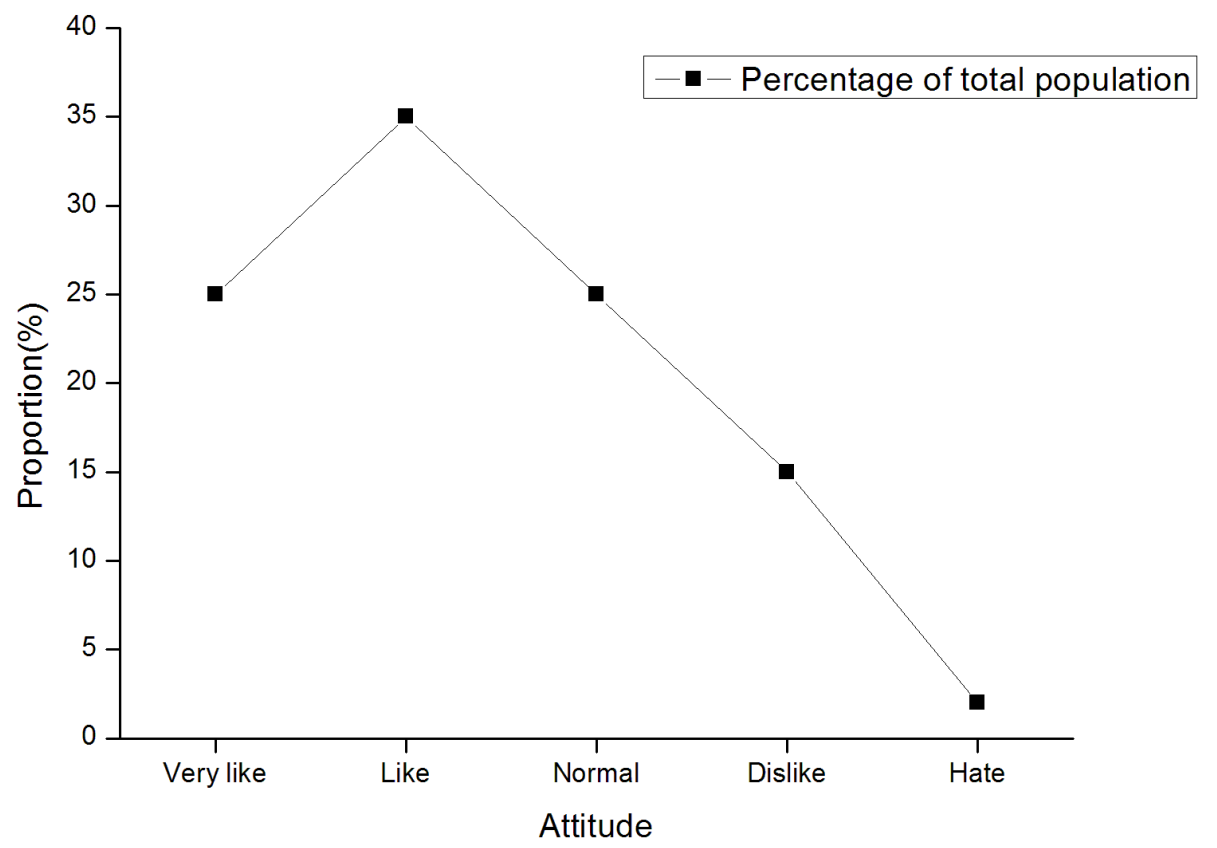

Fig. 5. Urban junior high school students' preference for listening to music in music class

This image is a sample survey of the degree of in-class music fondness for junior high school students in urban areas. 15 students dislike and hate to listen to music in music class, accounting for $17 \%$ of the total; 54 of them like and love to listen to music in music class, accounting for $71 \%$ of the total; and 20 students hold a neutral attitude towards music playing in music class, whose percentage is $22 \%$. 
This image is a sample survey of the degree of in-class music fondness for junior high school students in towns. None of them dislike and hate to listen to music in music class; 74 of them like and love to listen to music in music class, accounting for $72 \%$ of the total; and 29 students hold a neutral attitude towards music playing in music class, whose percentage is $28 \%$.

Through the survey we can see that either rural or urban students in junior high schools like to listen to music in music class, whose proportion is higher than those disliking or hating music playing in class. Compared to rural students, there are more urban students who do not like to listen to music in music class.

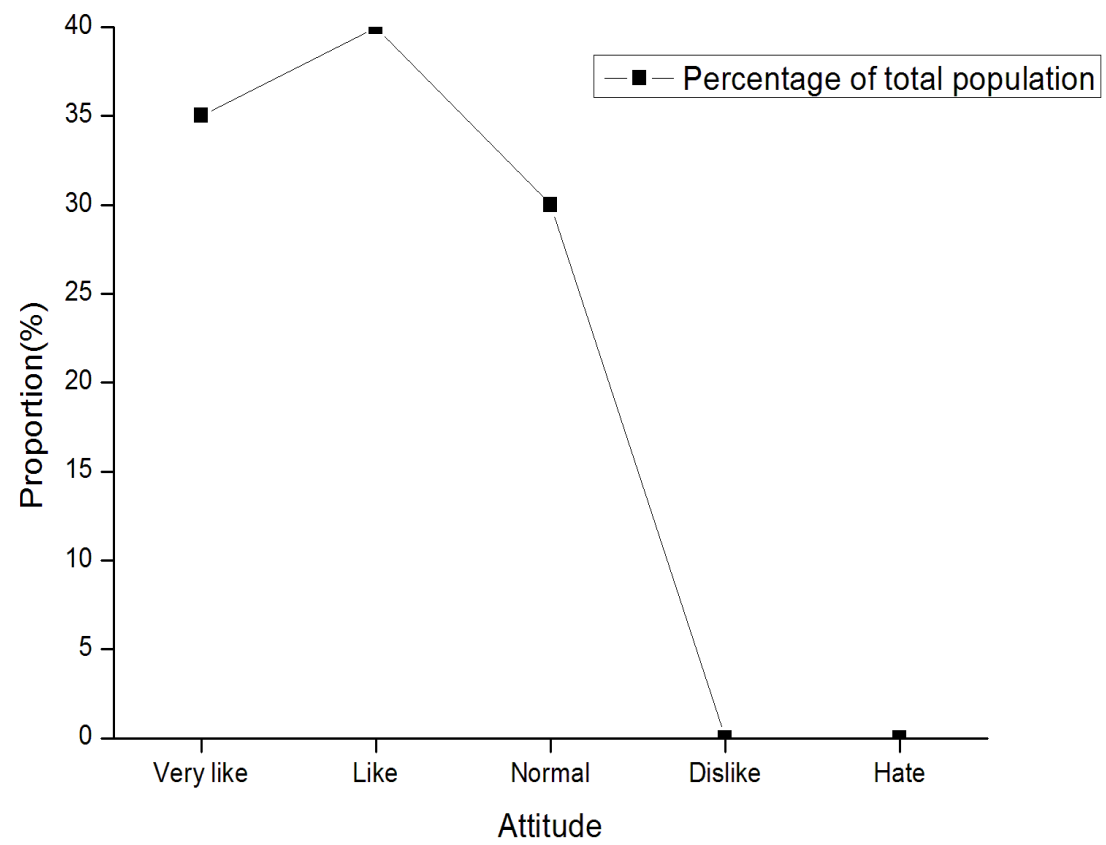

Fig. 6. Township junior high school students' preference for listening to music in music class

\section{Conclusion}

The application of computer music software in music learning helps strengthen students' learning initiatives. Through surveys, we find that most students perceive the charm of music by using computer music software, thinking it a pleasure rather than tediousness to learn music. Music creation is an important part of music practice and occupies an important position in music learning. When computer music software is used as a tool of music teaching, only by grasping the basic knowledge and skills of information technology can students learn music in the software. Through music learning, students and teachers will evidently have their information competence improved. As the language version of most of the computer music software is English, students and teachers will understand English better. 
The research of this subject allows full play to the advantages of computer music software and involves the application of computer music software in primary music teaching. Because of the limited energy and knowledge, there are still many issues to discuss in this project, pending further research.

\section{References}

[1] Portowitz, A., Peppler, K. A., \& Downton, M. (2014). In harmony: a technology-based music education model to enhance musical understanding and general learning skills. International Journal of Music Education, 32(2), 242-260. https://doi.org/10.1177/025576 1413517056

[2] Efuwape, B. M., \& Aremu, A. (2013). Gender differences in acceptability and usability of computer based learning package in electrical and electronics technology in Nigeria. American Journal of Educational Research, 1(10), 419-424. https://doi.org/10.12691/ education-1-10-2

[3] Cayari, C. (2015). Participatory culture and informal music learning through video creation in the curriculum. International Journal of Community Music, 8(1), 41-57(17). https://doi.org/10.1386/ijcm.8.1.41 1

[4] Upitis, R., \& Brook, J. (2016). How much professional development is enough? meeting the needs of independent music teachers learning to use a digital tool. International Journal of Music Education, 35(1), 93-106. https://doi.org/10.1177/0255761415619426

[5] Kraus, N. (2012). Biological impact of music and software-based auditory training. Journal of Communication Disorders, 45(6), 403-410. https://doi.org/10.1016/j.jcomdis.2012. 06.005

[6] Fang, Y., \& Teng, G. F. (2015). Visual music score detection with unsupervised feature learning method based on k-means. International Journal of Machine Learning \& Cybernetics, 6(2), 277-287. https://doi.org/10.1007/s13042-014-0260-2

[7] Myllykoski, M. (2012). Open-source software projects in music education: stakeholders, structure and the development cycle. Journal of Music, 5(2), 159-170. https://doi.org/10.1386/jmte.5.2.159 1

[8] Pérez, L., \& Cambrafierro, J. (2015). Learning to work in asymmetric relationships: insights from the computer software industry. Supply Chain Management, 20(1), 1-10. https://doi.org/10.1108/SCM-12-2013-0468

[9] Wang, X., Zhang, D., Wang, X., \& Zhang, D. (2017). A study on the influence of computer corpus software on college students' English vocabulary learning. International Journal of Emerging Technologies in Learning, 12(8), 27-35. https://doi.org/10.3991/ ijet.v12i08.7137

[10] Liu, T. Y. (2016). Using educational games and simulation software in a computer science course: learning achievements and student flow experiences. Interactive Learning Environments, 24(4), 1-21. https://doi.org/10.1080/10494820.2014.917109

\section{$7 \quad$ Authors}

Baihui Yan and Qiao Zhou are with Add Jiangxi Science \& Technology Normal University, Nanchang, Jiangxi, China.

Article submitted 09 November 2017. Published as resubmitted by the authors 13 December 2017. 